\title{
Correction to: Frequency of heterozygous germline pathogenic variants in genes for Fanconi anemia in patients with non-BRCA1/ $B R C A 2$ breast cancer: a meta-analysis
}

\author{
Blanche P. Alter ${ }^{1} \cdot$ Ana F. Best ${ }^{2} \mathbb{D}$
}

Published online: 8 July 2020

๑) Springer Science+Business Media, LLC, part of Springer Nature 2020

\section{Correction to:}

Breast Cancer Research and Treatment (2020) 182:465-476

https://doi.org/10.1007/s10549-020-05710-6

In the original publication of the article, the first sentence in the abstract was published incorrectly.

The corrected sentence should read as "Germline pathogenic variants in BRCA1 (FANCS) and BRCA2 (FANCDI) do not explain all familial or sporadic cases with breast cancer".
Publisher's Note Springer Nature remains neutral with regard to jurisdictional claims in published maps and institutional affiliations.

The original article can be found online at https://doi.org/10.1007/ s10549-020-05710-6.

Blanche P. Alter

alterb@mail.nih.gov

1 Clinical Genetics Branch, Division of Cancer Epidemiology and Genetics, National Cancer Institute, 9609 Medical Center Drive, Room 6E452, Rockville, MD 20850-9772, USA

2 Biostatistics Branch, Biometric Research Program, Division of Cancer Treatment and Diagnosis, National Cancer Institute, Bethesda, MD, USA 